\title{
Jamu: Javanese Doping during the Covid-19 Pandemic
}

\author{
Akhodza Khiyaaroh ${ }^{1}$, Atik Triratnawati ${ }^{2}$ \\ Department of Anthropology, Faculty of Cultural Sciences, Universitas Gadjah Mada \\ ${ }^{1}$ Mahasiswa Program Studi S1 Antropologi Budaya \\ ${ }^{2}$ Dosen Departemen Antropologi \\ Email:akhodza.k@gmail.com
}

Keywords: Jamu, doping, Javanese, Covid-19

Abstract: $\quad$ Jати is a part of traditional medicine that draws many people's attention today. This can be seen in the increasing consumption of jamu in Indonesian society. This increase can be influenced by the decision of the Indonesian people to consume jamu. This study revealed the reasons behind the choice of jamu as an effort to prevent Covid-19 in some Indonesian people, especially in rural Javanese people where jamu is very closely related to their lives. This research was conducted in Mojorejo Village, Kebonsari District, Madiun Regency by involving 20 informants obtained through purposive sampling technique. This research was conducted from April to June 2021. The ethnographic method was used to enable the researchers to dig deeper into the informants' experiences regarding herbal medicine. The researchers analyzed the research data by coding and included secondary data to enrich the findings.

Rural Javanese people choose јати as doping during the Covid-19 pandemic for three reasons, including the tradition of drinking jamu, its immune booster properties, and the 3M (mudah, murah, manjur) [Easy, Cheap, Effective] aspects of јати. Јати ingredients that include ginger, curcuma, aromatic ginger, turmeric, and tamarind are believed to be able to boost their immune system during the pandemic.

\section{INTRODUCTION}

Jamu has long been a part of Javanese people's life. Jamu is the nation's ancestral heritage that has been consumed for generations, both as a means of treatment and health maintenance. Indonesian people adopt a healthy lifestyle and traditional methods to maintain health and prevent illness (Bawono, 2011). Bawono (2011) also added that most people still consume traditional medicine, in this case jamu, to increase immunity.

Research conducted by the Health Research and Development Agency in 2010 showed that almost half of Indonesia population consumes jamu for the two purposes mentioned above (Andriati \& Wahjudi, 2016). Other research on the consumption of jamu also shows similar results. In the same year, the results of the Basic Health Research (Riskesdas) showed that jamu is consumed by more than fifty percent of Indonesian people (Purwaningsih, 2013).

In 2020, the consumption of jamu increased. This increase affects the production of jamu which is part of traditional medicine. The National Agency of Drug and Food (Badan POM) Control of the Republic of Indonesia's licensing data of 2020 showed an increase in the number of applications for registration of traditional immunity-boosting medicinal products by $131.14 \%$ (Badan POM,
2021). This figure represented an increase of more than two times higher compared to that of the initial period of the Covid-19 pandemic. As reported on the pom.go.id page, the increase had to do with the trend towards the use of jamu which is believed to increase the body's immunity, thus helping to prevent virus infection (Badan POM, 2021). Such an increase in the consumption of jати occurs throughout Indonesia, including in the Javanese community.

In the life of the Javanese people, јати is said to be a unique traditional medicine inherited from their ancestors (Mulyani et al., 2016). The study showed that Javanese people are more identifiable by their habit of consuming jamu than other communities in Indonesia. A study by Geertz (1983) showed that jamu is a traditional medicine that is the result of a culture known by the Javanese people since ancient times. Javanese people are believed to have remarkable ancient knowledge about traditional medicines (Bawono, 2011). The study of Purwaningsih (2013) later showed that, unlike with the Javanese people, the use of jamu in various regions and/or ethnic groups in Indonesia has not been well documented.

One of the Javanese communities that fits the above context is the people of Mojorejo Village, 
Kebonsari District, Madiun Regency. Based on the 2020 village monograph data, most of the villagers in that particular area are farmers ( 2493 people) and entrepreneurs (352 people). The large proportion of farmers in the village population can be seen from the paddy fields that dominate the area of Mojorejo Village compared to land used for other purposes. Of the total land area of Mojorejo Village of 228.68 ha, 120.70 ha is paddy field. The data indicate that agriculture is the main livelihood sector of Mojorejo Village as is found in many rural Javanese communities. The large proportion of farmers likely relate to most Mojorejo people's choice in boosting their body immunity.

Expected to strengthen the body's immune system, several types of jати ingredients are consumed as immune boosters, including Curcuma, turmeric, kencur (aromatic ginger), tamarind, and ginger. In addition to these main ingredients, other ingredients can also be added to add flavor and give an appetizing aroma such as cinnamon, lemongrass, and palm sugar (Kusumo et al., 2020). The study explained some of the benefits of the main ingredients above, apart from being an immune booster. Temulawak (Curcuma zanthorrhiza) contains curcuminoids that help the metabolic and physiological processes of the body's organs. Practically, temulawak is widely consumed to treat indigestion, jaundice, and vaginal discharge. Ginger (Zingiber officinale) contains essential oils and active chemical compounds that have antiinflammatory and antioxidant properties. The contents of the ginger rhizome make it efficacious in preventing and treating various diseases. In addition, ginger itself is known as a medicinal plant that is useful for strengthening the immune system. Turmeric (Curcuma domestica) functions as the best antibiotic and facilitates the digestive process and improves intestinal passage. These three ingredients contain curcumin which has many benefits due to its antioxidant, antibacterial, antiinflammatory, and antiviral properties. Various benefits in these herbs are needed to maintain the body's immunity while preventing the entry of viruses and bacteria into the body (Kusumo et al., 2020). The benefits contained in the various herbs above are of course very useful in the current Covid19 pandemic.

This culture of consuming herbal medicine by rural Javanese communities is an important aspect that underlies the increase in herbal consumption during the Covid-19 pandemic. Јати is then consumed not only of habit but also as doping. In defining the term doping, this present study limited the meaning of doping to what D'Angelo \& Tamburrini (2010) call a preventive-therapeutic approach to doping. In their writing, they argue that doping can be observed and understood as something the consumption of which can be controlled and does not cause any addictive effects. D'Angelo \& Tamburrini (2010) explain that in the realm of sports, the use of doping can be controlled and programmed in such a way that the consumers, in this case, the athletes, do not become addicted to certain drugs. They also add that this preventivetherapy approach to doping can also reduce violence against users due to the negative stigma against doping users and the anti-doping movement. Finally, it is reiterated that doping use is not an addiction, but is defined as a sign or symptom of social and economic dependence created by the highly competitive elite sports system among athletes (D'Angelo \& Tamburrini, 2010).

In line with the opinion of D'Angelo and Tamburrini (2010) regarding doping, a lecturer at the Faculty of Sports Science, Yogyakarta State University explained that, under certain conditions, doping does not necessarily endanger the health of athletes (Margono, 2004). Based on his point of view, the use of doping today has become a personal choice of its users. Regarding the consumption of јати, Javanese people also have various ingredients, which frequency of each ingredient's use is adjusted to the condition of the body. This shows that although јати is defined as doping, it does not necessarily make the users addicted. In this case, the function of jати as doping is to increase the body's immunity and prevent the entry of viruses or bacteria that cause diseases. One thing that makes herbal medicine can be seen as doping is its longterm consumption. In this context, јатu as doping has nothing to do with drugs that can harm the function of the body's organs. Jamu is part of traditional medicine that has many benefits, especially to increase the body's immunity.

During the Covid-19 pandemic, jamu can be an option to increase the body's immunity considering that Covid-19 is a disease that is easily transmitted through droplets of people coughing, air, and surfaces that have been contaminated with Covid-19 (Atmadja et al., 2020). Maintaining the body's immunity allows the body to stay healthy and immune to viruses that cause diseases. For the people of Mojorejo Village, the implementation of the prescribed health protocol regarding Covid-19 (wearing masks, maintaining distance, washing hands, reducing mobility, staying away from crowds) is less effective considering the many community activities they carry out together. Javanese rural communities then use јати as the main choice in their efforts to increase body immunity during the Covid-19 pandemic. This 
study revealed the reasons behind the rural Javanese people's behavior of making јати the main choice in increasing body immunity during the Covid-19 pandemic.

\section{RESEARCH METHODS}

This present research was qualitative research that emphasizes knowing the subject being studied and making sense of what the subject experiences in everyday life. In general, qualitative research is defined as research that applies multiple methods in a focus that involves an interpretive approach to each subject matter (Gumilang, 2016). In qualitative research, the researcher is involved in the context, situation, and setting of a natural phenomenon under the topic being studied. This makes each phenomenon unique and different from the others because the contexts are different (Nugrahani, 2014). This research was getting started with brief research about the location and informants. Then, selecting informants with some considerations related to the research topic. The selected informants were being interviewed in this research. In-depth-interview was being used to dig deeper about community's culture and characteristic, and collect data as comprehensive as possible.

The study was carried out in Mojorejo Village, Kebonsari District, Madiun Regency with 20 participants who were selected with purposive sampling technique. A purposive sampling technique is carried out with certain considerations which may vary depending on the needs of the research (Maharani \& Bernard, 2018). The considerations regarding the selection of informants in this present study were related to the local people's social and economic backgrounds.

To obtain qualitative data, the data were collected from the informants with an ethnographic method. According to Windiani (2016), ethnography is a qualitative research approach that seeks to explore a society's culture. The use of an ethnographic method usually aims to describe a culture as a whole, which includes all aspects of that culture, including those that are tangible like cultural artifacts (tools, clothes, buildings, etc.) and intangible like the experience, belief, norm, and value system of the society under study (Zakiah, 2008). In Mojorejo Village in which the people have their own experience about consuming jamu, this method was being used to explore a society's culture. In addition, an ethnographic method was a way to collect a holistic and comprehensive data about intangible aspect of Javanese people's culture related to jати consumption.
The primary data obtained from the informants were then analyzed based on previous readings from a cultural perspective. The previous readings as secondary data were in the form of articles related to the topic under study. The secondary data served as supporting information about the phenomena that occur in the studied community. Besides, the secondary data used in this paper also served to clarify phenomena in the community that still unclear.

\section{RESULTS AND DISCUSSIONS}

\section{The Closeness of Jamu to Rural Javanese Community}

Ideas, thoughts, and values embodied in human behavior are part of the culture. Knowledge of the use of medicinal plants in the prevention and treatment of illness is one of the cultural heritage of the Indonesian people which is based on experience, knowledge, and skills that have been passed down for generations (Perdani \& Hasibuan, 2021). This makes herbal medicine an inseparable part of the life of the Indonesian people, especially the Javanese. Javanese people are quite knowledgeable about herbal medicine. A person's knowledge of health can be seen from their knowledge about ways to maintain health. Health knowledge indicators can be identified through an understanding of illness and disease, healthy lifestyles, and knowledge about environmental health (Zulaikha et al., 2021). In Mojorejo Village, people's knowledge about health is based on personal experience and that of people around them, including knowledge about јати that can overcome the symptoms of various diseases. The existence of jamu has been known for generations, the consumption of which has become a habit in rural Javanese communities.

To date, the types of jamu that are commonly consumed by the Javanese people are kunyit asam made from turmeric and tamarind and beras kencur made from aromatic ginger and rice. Apart from being introduced from an early age, the Javanese people's habit of consuming kunyit asam and beras kencur is caused by the many sellers of jamu who walk around their neighborhood to offer various types of jати. The majority of informants said they know јати from their parents and mobile јати sellers. One of the informants named Riky (27) said, "I drink jати if only there is jати sellers pass by".

The majority of herbal medicine sellers offer beras kencur and kunyit asam the tastes of which tend to be sweet, whereas other types of jamu ingredients are prepared according to the individual consumers' demands and nowadays people's 
consumption of bitter-tasting jamu ingredients is decreasing. Consumers' demand is evolving. Unlike the older generations of rural Javanese people who prioritized the efficacy of jamu, nowadays people tend to prefer jamu ingredients which can also be consumed as delicious and refreshing drinks. Many informants said that they used to buy jamu from mobile sellers because it is practical, healthy, refreshing, and tastes good. This phenomenon shows that the consumption of jamu is increasingly influenced by human nature as a homo economicus creature who prioritizes consumption that is considered the most profitable at a low cost rather than the efficacy of jamu alone.

Kunyit asam ingredient includes turmeric rhizome (Curcuma domestica) which contains curcuminoid compounds such as curcumin, desmethoxycumin, and bisdesmethoxycurcumin. Turmeric rhizome is efficacious for maintaining stamina and have hepatoprotection, diuretic, antioxidant, anti-inflammatory, immunomodulatory, cough relieving, and anticancer properties, to name a few (Mulyani et al., 2016). The high levels of antioxidants in tamarind (Tamarindus indica) make kunyit asam even more efficacious ingredient. As for kencur (aromatic ginger) (Kampferia galanga), it contains starch, minerals, flavonoids, alkaloids, and essential oils which are efficacious for treating coughs, shedding phlegm, clearing the throat, removing mucus that clogs the nose, and warming the body (Mulyani et al., 2016). The mixture of kencur and rice adds to the antioxidant effect of beras kencur ingredient.

\section{Jamu as Immune Booster}

The term immune booster has now become familiar among the Indonesian people, especially the Javanese. The immune-boosting efforts lead to activities that can increase immunity. The Covid-19 pandemic forces the Javanese people to make efforts to increase body immunity. Sunbathing is one of the chosen efforts to increase the body's immunity during the Covid-19 pandemic. This particular effort is inspired by the daily activities of rural Javanese farmers do in the rice fields. The informants of this study thought that while in the fields, both in the morning and the afternoon, their bodies would become fitter from engaging in many activities the farmers usually do in the field, including hoeing (macul), pulling weeds (matun), and spreading fertilizer (ngrabuk). Mr. Edy (55) said, "Just by going to the fields is already sweating. There I hoeing (macul), pulling weeds (matun), and spreading fertilizer (ngrabuk)".

This gave the rural Javanese people an idea of what to do during sunbathing routines. Over time, they became realized that they do not necessarily go to the fields every day because the need to do so depends on the condition of the fields; if the rice fields are adequately irrigated, free from pests, and receive sufficient fertilizer, for example, then the farmers do not need to go to the fields. This makes them need to think about other efforts that can increase their body immunity.

Jamu is then chosen by the community as doping during the Covid-19 pandemic. One type of herbal ingredients that is widely consumed as doping during the Covid-19 pandemic is wedang jahe (hot ginger drink). Wedang jahe is a drink made by mixing hot water and ginger that has been crushed a bit, added with honey or sugar (Koswara, 2006). Wedang jahe can be considered as jamu because the properties and ingredients are similar to what are contained in jamu. The ginger rhizome contained in wedang jahe has many benefits. Ginger (Zingiber officinale) is used as herbal medicine because it contains essential oils with active chemical compounds, such as zingiberin, camphor, lemonin, borneol, shogaol, cineol, fellandren, zingiberol, gingerol, and zingeron which are efficacious in preventing and treating various diseases. Besides, active chemical compounds such as gingerol, beta-carotene, capsaicin, cafeic acid, curcumin, and salicylic properties which are antiinflammatory and antioxidant (Aryanta, 2019) are also contained in ginger. The content in ginger has antioxidant and anticancer effects. In addition, ginger rhizome also contains essential oils that are useful for treating headaches, stomachaches, dizziness, and colds. Associated with colds, the benefits or efficacy of ginger as a carminative that makes ginger effective for shedding farts and expelling gas. Other benefits of ginger include increasing appetite and strengthen the stomach, as well as serving as a stimulant and diaphoretic or sweat laxative (Mulyani et al, 2016).

Most of the informants in this study consume wedang jahe to increase the body's immunity. The assumption that underlies the choice of wedang jahe is that the properties of wedang jahe warm the body. A warm body will enable sweat secretion which in turn makes the body fitter and fresher. Rural Javanese people believe that when sunbathing cannot be done every day it can be substituted by consuming wedang jahe which is very familiar among them. Mrs. Rubiyah (51) said, "I consume wedang jahe to increase my body's immunity because it can warm my body. Wedang jahe makes me sweating and I feel fitter". Drinking wedang jahe is likened to sunbathing because it warms the body and thus enables sweat secretion. In addition to its association with sunbathing wedang jahe also 
has many other properties that are useful for preventing and treating illnesses that are commonly experienced by rural Javanese communities such as colds, headaches, chills, and others.

\section{The 3M (Mudah, Murah, Manjur) Aspects of Jamu}

The use of jamu as doping during the Covid19 pandemic is almost like a reflex response for rural Javanese communities. The reason behind this is that the basic ingredients of jати are very easy to find. For Mrs. Mutmainah, Mrs. Fatimah, and Mrs. Rubiyah, they can get the basic ingredients for making jamu such as ginger and turmeric whenever they want. They have medicinal plants that have been long grown to maintain and support the consumption of herbal medicine.

Other informants, including Mrs. Ida, Mrs. Muti'ah, and Mrs. Pipit buy basic ingredients of јати while shopping staple goods at the market. The location of the market which is not far from home also allows them to supply the basic ingredients for preparing јати. Like what Mrs. Muti'ah (60) said, "I buy the basic ingredients of wedang jahe. Every morning I go to market to buy basic ingredients for today's menu and staple goods to be sold in my store. But for other kinds of jamu like kunyit asam and beras kencur I always buy them from mobile jamu seller". For the gentlemen who decide to buy ready-to-drink jати at the jати depots, an owner of jamu stall named Ihsanudin admitted that he always had consumers to serve. This shows that jamu can still be easily accessed by rural Javanese communities.

In terms of price, those who grow medicinal in their garden are certainly free from the costs incurred for consuming јати, whereas for those who have to buy the basic ingredients of jати in the market the price is still affordable even though the price temporarily soared due to soaring demand at the beginning of the pandemic. They usually buy јати ingredients that can be used for two days for family consumption or four to five days for individual consumption. Related to that, Mrs. Sofi (50) said, "I drink wedang jahe because it is made by natural ingredients, easy to find, and the price is affordable". The price of ready-to-drink jamu at jати stalls is also quite affordable. One of the informants named Mr. Edy revealed that there are 3 classes of prices at the jати stall, namely regular, special, and very special. They are sold at IDR 10,000, IDR 12,000, and IDR 15,000 per glass, respectively. Therefore, the existence of basic ingredients for herbal medicine and herbal medicine itself is still very affordable.
The interviews with rural Javanese people revealed that јати is considered to have properties that can be felt directly. The informants revealed that the benefits felt after consuming herbal medicine include that the body felt fresher, less likely to become ill, and fitter. In addition, the various benefits mentioned earlier are also directly felt, which increase their belief in јати and thus rely on it to prevent or treat various diseases. These findings are in line with a study that shows rural Javanese people tend to use јати because it is considered a tradition, easy and cheap to access, and effective (Triratnawati, 2010).

For the Javanese communities, Covid-19 is considered a new disease, but their response is associated with a local frame of reference, namely folk medicine that has been known for generations (Hardon et al., 1995). Јати as folk medicine then becomes the main choice because it has been long known as herbal medicine and people were accustomed to consuming it. The choice of this form of treatment cannot be separated from the concept of medical pluralism that exists in Javanese society. They consider traditional treatment options such as jати to be complementary to and do not conflict with modern medical treatment (Triratnawati, 2019). Therefore, јати as doping during the Covid 19 pandemic is considered a way to preserve traditional medicine culture while at the same time strengthening local identity against global medical attacks that have a strong influence in the world.

\section{CONCLUSION}

Rural Javanese people choose jamu as doping to increase body immunity during the Covid-19 pandemic. Three reasons underlie the choice, including the closeness of јати to rural Javanese communities, its immune booster properties, and the 3M (Mudah, Murah, Manjur [Easy, Cheap, Effective]) aspect. Јати is a traditional medicine that has been known for generations. Although the currents of globalization and various changes continue to enter and influence the mindset of the rural Javanese people regarding health, they still prefer јати because its existence is very close to them, and consuming јати has become a habit. Besides, jати has also been proven to be effective as an immune booster due to the properties contained in some ingredients. The assumptions and experiences of the local community regarding the efficacy of jamu, which are supported by scientific data, have made јати the main choice to increase body immunity during the Covid-19 pandemic in addition to other efforts to maintain immunity.

The 3M aspect of jати makes people more encouraged to consume it. These three aspects are 
sufficient to convince the public about what kind of doping they need in the current Covid-19 pandemic context. Regardless of how the local people obtain јати, they still have no difficulty in obtaining it, are not bothered by its price, and feel the direct benefits from consuming it. Rural Javanese communities do not need to worry about anything related to Covid19 prevention efforts as long as these three aspects are still attached to јати.

\section{REFERENCES}

Abdillah, L. A. (2020). Stigma terhadap Orang Positif Covid-19. 11-24.

Achmad, Z. A., \& Ida, R. (2018). Etnografi Virtual sebagai Teknik Pengumpulan Data dan Metode Penelitian. The Journal of Society \& Media, 130-145.

Aditama, T. Y. (2014). Jamu \& Kesehatan. Jakarta: Lembaga Penerbit Balitbangkes.

Andriati, \& Wahjudi, T. R. (2016). Tingkat Penerimaan Penggunaan Jamu Sebagai Alternatif Penggunaan Obat Modern pada Masyarakat Ekonomi Rendah-Menengah dan Atas. Masyarakat, Kebudayaan dan Politik, 133-145.

Aryanta, I. W. (2019). Manfaat Jahe untuk Kesehatan. Widya Kesehatan, 39-43.

Atmadja, T. F., Yunianto, A. E., Yuliantini, E., Haya, M., Faridi, A., \& Suryana. (2020). Gambaran Sikap dan Gaya Hidup Sehat Masyarakat Indonesia selama Pandemi Covid19. AcTion: Aceh Nutrition Journal, 195-202.

Bagus, A. P., \& Triratnawati, A. (2021). The Edge as The Choice (A Case Study of Jamu Sellers in Three Traditional Markets, Yogyakarta City). Indonesian Journal of Medical Anthropology, 17.

Bawono, A. (2011). Kontribusi Religiusitas dalam Perilaku Pengambilan Keputusan Konsumsi . Jurnal Muqtasid, 115-133.

D'Angelo, C., \& Tamburrini, C. (2010). Addict to Win? A Different Approach to Doping. Journal of Medical Ethics, 700-707.

Djamaludin, M. D., Sumarwan, U., \& Mahardikawati, G. N. (2009). Analisis Kepuasan dan Loyalitas Konsumen Jamu Gendong di Kota Sukabumi. Jurnal Ilm. Kel. dan Kons., 174-184.

Drajat, A. R., Pamungkas, J., Setiawan, H. T., \& Hilmi, F. (2020). Pengembangan Usaha Jamu Herbal untuk Meningkatkan Imunitas Tubuh dalam Menghadapi Pandemi Covid-19. Civitas Ministerium, 61-68.
Gumilang, G. S. (2016). Metode Penelitian Kualitatif dalam Bidang Bimbingan Konseling. Jurnal Fokus Konseling, 144-159.

Harliansyah, F. (2010). Triangulasi dalam Penelitian Kualitatif.

Harwati, T. (2009). Khasiat Jahe bagi Kesehatan Tubuh Manusia. INNOFARM: Jurnal Inovasi Pertanian, 54-61.

Ilpaj, S. M., \& Nurwati, N. (2020). Analisis Pengaruh Tingkat Kematian Akibat Covid-19 terhadap Kesehatan Mental Masyarakat di Indonesia. Jurnal Pekerjaan Sosial, 16-28.

Koswara, S. (2006). Jahe, Rimpang dengan Sejuta Khasiat.

Kurniasih, S., \& Pratama, I. M. (2020). Prototipe Jendela Kaca untuk Ruang Berjemur dalam rangka Meningkatkan Imunitas Tubuh. Jurnal Arsitektur, 269-275.

Kusumo, A. R., Wiyoga, F. Y., Perdana, H. P., Khairunnisa, I., Suhandi, R. I., \& Prastika, S. S. (2020). Jamu Tradisional Indonesia: Tingkatkan Imunitas Tubuh Secara Alami Selama Pandemi. Jurnal Layanan Masyarakat, 465-471.

Maharani, S., \& Bernard, M. (2018). Analisis Hubungan Resiliensi Matematik terhadap Kemampuan Pemecahan Masalah Siswa pada Materi Lingkaran. Jurnal Pembelajaran Matematika Inovatif, 819-826.

Margono. (2004). Doping, Fair Play, dan Kehidupan Sosial. 1-6.

Mulyani, H., Widyastuti, S. H., \& Ekowati, V. I. (2016). Tumbuhan Herbal sebagai Jamu Pengobatan Tradisional terhadap Penyakit dalam Serat Primbon Jampi Jilid I. Jurnal Penelitian Humaniora, 73-91.

Neyman, J. (1934). On the Two Different Aspects of the Representative Method: The Method of Stratified Sampling and the Method of Purposive Selection. Journal of the Royal Statistical Society, 558-625.

Nugrahani, F. (2014). Metode Penelitian Kualitatif dalam Penelitian Pendidikan Bahasa. Surakarta.

Perdani, M. S., \& Hasibuan, A. K. (2021). Analisis Informasi Tanaman Herbal melalui Media Sosial di Tengah Masyarakat pada Pandemi Covid-19: Sebuah Tinjauan Literatur. Bencoolen Journal of Pharmacy, 11-25.

POM, B. (2021, May 27). Badan POM Ajak Masyarakat Bijak Membeli Obat Tradisional Online di Masa Pandemi. Dipetik June 11, 2021, dari

https://www.pom.go.id/new/view/more/berita/2 2374/Badan-POM-Ajak-Masyarakat-BijakMembeli-Obat-Tradisional-Online-di-MasaPandemi.html 
Purwaningsih, E. H. (2013). Jamu, Obat Tradisional Asli Indonesia Pasang Surut Pemanfaatannya di Indonesia. eJKI, 85-89.

Sinaga, R. M., Zuska, F., \& Sitorus, P. (2021). Indegenous Healer Knowledge About Illness anf The Way to Make Traditional Medicine. Indonesian Journal of Medical Anthropology, 43-47.

Siregar, R. S., Salsabila, \& Siregar, A. F. (2021). Analisis Hubungan Sikap dan Tingkat Pengetahuan terhadap Perilaku Masyarakat Kota Medan Mengonsumsi Jamu Tradisional di Masa Pandemi Covid-19. 13-22.

Triratnawati, A. (2010). Pengobatan Tradisional, Upaya Meminimalkan Biaya Kesehatan Masyarakat Desa di Jawa. Jurnal Manajemen Pelayanan Kesehatan, 69-73.

Trisiana, A., A, S. R., R, A. F., M, L. A., Syaibani, I., \& F, S. N. (2020). Menumbuhkan Kesadaran Masyarakat Indonesia untuk Memutus Rantai Penyebaran Wabah Covid-19. Jurnal Global Citizen, 51-62.

Utami, F. P., Matahari, R., \& Ikhsanudian, A. (2018). TOGA (Manfaat dan Cara Pengolahannya). Yogyakarta: Penerbit Pustaka Ilmu.
Vitayanti, N. (2020). Data Potensi Desa. Madiun: Desa Mojorejo.

Vitayanti, N. (2020). Data Tingkat Perkembangan Desa. Madiun: Desa Mojorejo.

Windiani, \& R, F. N. (2016). Menggunakan Metode Etnografi dalam Penelitian Sosial. Dimensi, 8792.

Zakiah, K. (2008). Penelitian Etnografi Komunikasi: Tipe dan Metode. Mediator, 181188.

Zendrato, W. (2020). Gerakan Mencegah daripada Mengobati terhadap Pandemi Covid-19. Jurnal Education and Development, 242-248.

Zulaikha, S., Hadi, N., \& Purwasih, J. H. (2021). Melemahnya Budaya Jamu Cekok di Kelurahan Pare. Jurnal Antropologi: Isu-Isu Sosial Budaya, 47-57. 